ERRATUM

\title{
Cryptic species complexes in manipulative echinostomatid trematodes: when two become six - ERRATUM
}

Leung, T. L. F., Keeney, D. B. and Poulin, R.

doi:10.1017/S0031182008005374, Published by Cambridge University Press, 18 December 2008.

First published online 30 Fanuary 2009

A new Table 1 has been supplied by the authors in which the number of samples from Papanui Inlet and the Total number of samples in the last two lines of the table have been corrected.

Table 1. Sampling site and number of Curtuteria spp. and Acanthoparyphium spp. samples

\begin{tabular}{|c|c|c|c|c|c|c|}
\hline \multirow[b]{2}{*}{ Sampling site } & \multicolumn{2}{|l|}{ Curtuteria } & \multicolumn{4}{|c|}{ Acanthoparyphium } \\
\hline & $\begin{array}{l}\text { Curtuteria } \\
\text { australis }\end{array}$ & $\begin{array}{l}\text { Curtuteria cryptic } \\
\text { species }\end{array}$ & Sp. A & Sp. B & Sp. C & Sp. D \\
\hline Company Bay & 0 & 0 & 14 & 0 & 0 & 0 \\
\hline Deborah Bay & 1 & 0 & 0 & 0 & 0 & 0 \\
\hline Lower Portobello Bay & 17 & 0 & 17 & 2 & 3 & 0 \\
\hline Turnbull & 0 & 0 & 13 & 0 & 1 & 0 \\
\hline Hooper's Inlet & 1 & 3 & 0 & 0 & 0 & 0 \\
\hline Papanui Inlet & 2 & 12 & 9 & 0 & 14 & 5 \\
\hline Total & 21 & 15 & 53 & 2 & 18 & 5 \\
\hline
\end{tabular}

